\title{
István Csernicskó
}

Ferenc Rákóczi II. Transcarpathian Hungarian Institute, Ukraine; University of Pannonia, Hungary

Réka Máté

University of Pannonia, Hungary; Ferenc Rákóczi II. Transcarpathian Hungarian Institute, Ukraine

\section{BILINGUALISM IN UKRAINE: VALUE OR CHALLENGE?}

Summary. Several analyses have summarized the linguistic situation of Ukraine, highlighting various aspects of the problematic issues of Ukraine's language policy. The fundamental problems of the linguistic situation in Ukraine are the lack of consensus regarding the issue of what role the Ukrainian language has in constructing the new postSoviet identity and in nation building, what status the Russian language should be given in Ukraine. According to the data from the 2001 census, $80 \%$ of the adult population of Ukraine speak (at least) one other language fluently in addition to their mother tongue. In the country it is clear that the reality in most of Ukraine is of bilingualism. Almost everyone in Ukraine is bilingual; to varying degrees, a fundamental characteristic of the language situation in Ukraine is bilingualism of society. In spite of this, due to negative historical experiences, bilingualism is stigmatized in Ukraine, and that makes codification of bilingualism impossible on the state level. The paper shows the attitude of the political elite that took power after the overthrow of President Viktor Yanukovych towards the issue of bilingualism. We present how the linguists and representatives of the intellectuals comment on the bilingualism in Ukraine. The primordial, national romantic view that makes the Ukrainian language and the (free and independent) Ukrainian nation the same nowadays strongly dominates in Ukraine.

Keywords: Ukraine, Ukrainian language, Russian language, language policy, language rights.

\section{Introduction}

The particular characteristics of the geopolitical and geographical position of Ukraine, the variable political, historical, economic, cultural and social development of the regions of its territory inherited from the Soviet Union, the ethnic and linguistic composition of its population, and the fact that the representatives of the titular nations of all neighbouring states are among its citizens all turn the issues of language into matters of internal and foreign policy as well as of security policy in this country. The military conflict currently underway is also indicative of this. 
Several analyses have summarized the linguistic situation of Ukraine, highlighting various aspects of the problematic issues of Ukraine's language policy (Taranenko, 2007; Besters-Dilger, 2009; Csernicskó \& Ferenc, 2016). The fundamental problems of the linguistic situation of Ukraine are the lack of consensus regarding the issue of what role the Ukrainian language has in constructing the new post-Soviet identity and in nation building, what status the Russian language should be given in Ukraine, and what functions can be assigned to other minority languages (Polese, 2011).

After the dissolution of the Soviet Union, the building of the Ukrainian nation was aided by the system of institutions inherited from the USSR (relatively clearly marked inner and outer borders, a parliament, ministries, representation in the UN, etc.), but at the same time, made difficult by the Russian community living in Ukraine, which became a minority overnight (Brubaker, 1996, p. 17). The presence of the sizeable Russian community has been felt primarily in the Ukrainian-Russian language struggles. Both researchers (Pavlenko, 2008, p. 275; Ulasiuk, 2012, p. 47) and the specialists of international organizations (Opinion, 2011, p. 7; UN, 2014) have repeatedly pointed out that the question of languages is heavily politicized in Ukraine, and the fact that it is not clearly settled can lead to the emergence of language ideologies as well as to conflicts of ethnic groups and languages. It is no coincidence that the Law on National Security ${ }^{1}$ regards, in Article 6 , the settling of the language issue as a priority among the country's national interests.

According to data from the 2001 census, $80 \%$ of the adult population of Ukraine speak (at least) one other language fluently in addition to their mother tongue (Lozyns'kyi, 2008, p. 254). In the country it is clear that "the reality in most of Ukraine is of bilingualism" (Bowring, 2014, p. 70). "Almost everyone in Ukraine is bilingual, to varying degrees" (Bilaniuk, 2010, p. 109). "A fundamental characteristic of the language situation in Ukraine is bilingualism of society" (Shumlianskyi, 2010, p. 135). In spite of this, due to negative historical experiences, bilingualism is stigmatized in Ukraine (Pavlenko, 2011, p. 52). The majority of the Ukrainian intelligentsia feel the bilingualism as a yoke (Vynnychuk, 2016) that makes codification of bilingualism impossible on the

1 Закон України „Про основи національної безпеки України”. Retrieved from: http://zakon4.rada.gov.ua/laws/show/964-15. 
state level (Csernicskó, 2017). The language law of 2012 which codifies bilingualism on a regional level is considered a Troian horse (Marusyk, 2016b). Our paper shows the attitude of the political elite that took power after the overthrow of President Viktor Yanukovych towards the issue of bilingualism. We present how the linguists and representatives of the intellectuals comment on the bilingualism in Ukraine.

\section{The Language Issue as a Factor of Political Mobilizing}

Ukraine, which gained its independence in 1991, is undergoing the worst crisis of its brief history. At the turn of 2013-2014 this crisis outgrew the borders of Ukraine. The annexation of the Crimea, the eastern Ukrainian armed conflict endangers the balance of the world's security policy; the political and economic sanctions against Russia and the responding opposing sanctions are obstructing the growth of world economy. The situation which is defined as the "Ukrainian crisis" in the international press is a consequence that is composed by different factors. The linguistic division of the country and the Ukrainian-Russian linguistic rivalry have also contributed to causing the political, military and economic crisis (Csernicskó, 2017).

The fight between the two dominant ethnic groups broke out because of the functions of the Ukrainian and Russian language. As a result, a paradoxical situation has risen in the language situation and the judgement of the state language policy of the minorities (amongst them the loudest are Russianspeaking) are dissatisfied with their guaranteed language rights, while the majority of the elite is worried about the current status and future of the Ukrainian language (Kulyk, 2014; Korostelina, 2013, p. 313).

The main cause of the language-issue-related demonstrations in recent history of Ukraine was the adoption of the new Language Act. ${ }^{2}$ After being defeated in the 2004 Orange Revolution, Yanukovych won the 2010 presidential election, the President and the Party of Regions behind him - according to election promises - he intended to base language policy on the real situation. They wanted to codify the country's de facto bilingualism by raising Russian into a

2 Закон України "Про засади державної мовної політики" Retrieved from: http://zakon3.rada.gov.ua/laws/show/5029-17. 
second state language status. The central part of their argument was that violent nationalism threatens linguistic and ethnic rights of the Russian-speaking population, it overshadows the Russian language and culture (Bowring, 2014). However, the right of free use of the Russian language was not only demanded in the southern and eastern regions, but also across the country, also in areas where the proportion of the Russian-speaking population is insignificant. The new power - ignoring the protest actions - began to rewrite the Constitution and the Language Act. They did not have the political power for the amendment of the Constitution: they did not get two-thirds of the votes in the Parliament. However, the 1989 language law from the Soviet times, has been replaced after scandalous and unworthy parliamentary scenes and political games.

The language law had a number of opponents. The Constitutional Court was repeatedly asked to declare it unconstitutional, organizing several protests in the streets. The language issue was not reassuring. In spring 2014 it has become a casus belli.

On 21 November 2013, it became apparent that the president of Ukraine - a country heading towards state bankruptcy at the time - was not going to sign the free trade agreement or the association agreement with the European Union in Vilnius. The Ukrainian government opted for a very favourable Russian loan rather than the IMF loan, which would have brought unpopular and strict austerity measures threatening its power.

On 23 November protests for Ukraine's European integration began in Kyiv. The protests organized in the city's main square ${ }^{3}$ were peaceful for a while and were called the Revolution of Dignity. On 30 November an unreasonably brutal use of force by the police propelled the lukewarm protests into a national movement. The parliamentary majority backing the president modified several laws on 16 January 2014, in order to limit people's right of assembly. This triggered the protests to escalate to uncontrolled violence which resulted in many casualties as well. The parliament repealed the laws of 16 January on 28 January, and Prime Minister Mykola Azarov resigned. On 22 February Yanukovych fled the country.

\footnotetext{
${ }^{3}$ Kyiv's central square is called майдан Незалежності (Independence Square) in Ukrainian. The locals usually refer to it as Майдан (Square), and it was called Maidan in news broadcasts, which, in turn, gave rise to the most often used name of the movement as Euromaidan/Євромайдан.
} 
A quick realignment occurred in the parliament. Representing different parties than before, the same members of the parliament formed a parliamentary majority which repealed the language law on 23 February, 2014. ${ }^{4}$ Russia immediately announced that it would defend the Russian speaking minority of Ukraine and protect it from Ukrainian nationalism. On the territory of Crimea, which was transferred in 1954 as the Crimean Autonomous Republic from the Russian Federation to the Ukrainian Soviet Socialist Republic, military personnel from the Russian army bearing no insignia of their affiliation (called little green men in popular discourse) appeared on the same day (Galeotti, 2015).

Russian President Vladimir Putin said the following in his speech during the ceremony regarding the annexation of the Crimea on 18 March 2014:

"... the residents of Crimea and Sevastopol turned to Russia for help in defending their rights and lives, in preventing the events that were unfolding and are still underway in Kiev, Donetsk, Kharkov and other Ukrainian cities. Naturally, we could not leave this plea unheeded; we could not abandon Crimea and its residents in distress. This would have been betrayal on our part. (...) Our concerns are understandable because we are not simply close neighbours but, as I have said many times already, we are one people. (...) Millions of Russians and Russian-speaking people live in Ukraine and will continue to do so. Russia will always defend their interests using political, diplomatic and legal means. But it should be above all in Ukraine's own interest to ensure that these people's rights and interests are fully protected. This is the guarantee of Ukraine's state stability and territorial integrity". ${ }^{5}$

Two and a half years after the beginning of the events of Donbass and the Crimea, Putin stated his opinion that due to steps taken by the Ukrainian power, Russia "was forced to defend Russian-speaking population of Donbass". 6

Temporarily filling the positions of both president and speaker of the parliament, Oleksandr Turchynov assessed the situation and decided, on 27 February, not to sign the document that would have repealed the language law of 2012, which thus remained in force. It was too late for a decision, and the

\footnotetext{
${ }^{4}$ Ukraine abolishes law on languages of minorities, including Russian (23-02-2014). Retrieved from:

http://rbth.co.uk/news/2014/02/23/ukraine_abolishes_law_on_languages_of_minorities_inc luding_russian_34486.html.

${ }^{5}$ See: http://en.kremlin.ru/events/president/news/20603.

6 See: http://korrespondent.net/ukraine/politics/3756878-putyn-vynudyly-zaschyschatrusskoiazychnykh-na-donbasse.
} 
attempt of the abolition of the 2012 language law become the pretext of the newest and most serious crisis in Ukraine.

The language issue was one of the main causes of the conflict that erupted in the eastern part of the country (Osnach, 2015). The attempt of the abolition of the language law - when a few hundred meters away from the representatives voting on this in parliament, thousands protested, gunmen looked at each other eye to eye, burned in fires - demonstrates how important and symbolic is the language issue in Ukraine.

\section{The Language Policy Amended in Order to Deal with the Crisis}

Instead of suddenly abolishing the language law Turchynov made a proposal to develop a new language law. ${ }^{7}$ He stated that the draft of the new law to be completed within a short period of time, "taking into account the existing speculations regarding the language issue." Turchynov also added that the new, balanced Language Act "will take into account the eastern and western parts of Ukraine, the interests of all ethnic groups and national minorities." The new language law has still not been born, but this step served to ease the tension, as the statement that Prime Minister Arseniy Yatsenyuk and Turchynov pledged on 18 April 2014, that the highly centralized state power will be decentralized and Russian will get a special status (Marusyk, 2015). ${ }^{8}$ The parliament on 20 May voted the "Memorandum of Understanding and Peace", in relation to the languages in which it says:

"In parallel with the status of the Ukrainian language as a state language the Supreme Council of Ukraine guarantees the insurance of the status of Russian language. The government will also guarantee the support for the languages of national minorities in minority areas compactly. ${ }^{\prime 9}$

"I hope - Petro Poroshenko said in a statement on 28 June 2014 - that in the history of Ukraine the issue of language or culture will never again threaten

\footnotetext{
7 See: http://iportal.rada.gov.ua/news/Novyny/Povidomlennya/88685.html.

8 Available online:http://www.slovoidilo.ua/news/2131/2014-04-18/yacenyuk-i-turchinovpoobecshali-russkij-yazyk-i-decentralizaciyu-vlasti.html.

9 Постанова Верховної Ради України Про меморандум порозуміння й миру. Retrieved from: http://zakon3.rada.gov.ua/laws/show/1280-18.
} 
the national unity, ${ }^{10}$ thereby acknowledging that the unsettled language problem is a security risk for the state.

After the overthrow of the regime of Yanukovych the elite that came to power is trying to become a leader in both sides. President Poroshenko in his post-election speech and in his New Year's speech made gestures towards the Russian-speaking citizens of Ukraine. At one point in his speech he switched to Russian. He also stated that one can love Ukraine in Russian as much as in Ukrainian. ${ }^{11}$ He added that $62 \%$ who fought for Ukraine in the east is Russianspeaking, and he thinks that the parliamentary decision, which deprived the status of Russian as the official language was a mistake, as this language issue has become a problem threatening national unity. ${ }^{12}$ The President was the supporter of a movement, which tried to reduce the tension in the country: the "Єдина країна - Единая страна" (single or integrated country) slogan (Ukrainian and Russian) was depicted on posters, billboards, leaflets, on national television, in the corner of video clips; it also has a dedicated page on the most popular Russian social network site. ${ }^{13}$

The President and the Prime Minister saw a direct link between the language issue and the country's already critical situation, and attempted to relieve the tension. However, this came too late. In April 2014 the recent domestic political developments overshadowed the case of the new language law. With the support of the Russian army an armed conflict broke out in EastUkrainian Donetsk and Luhansk counties. The euphemistically called "antiterrorist operation" - besides the country's extremely serious economic situation and unbalanced domestic politics - led to a severe crisis.

\section{Russian as "The Language of the Enemy", and the "Aggressor's Language"}

The tolerant language policy of the new Ukrainian power gives reason for nationalist intellectual circles to keep attacking the president (Osnach, 2015;

\footnotetext{
10 Available online: http://korrespondent.net/ukraine/politics/3385352-reshenye-olyshenyy-russkoho-yazyka-statusa-rehyonalnoho-bylo-oshybkoi-Porosenko.

${ }^{11}$ See: http://www.pravda.com.ua/news/2014/08/23/7035607/.

12 Available online: http://korrespondent.net/ukraine/politics/3385352-reshenye-olyshenyy-russkoho-yazyka-statusa-rehyonalnoho-bylo-oshybkoi-Porosenko.

${ }^{13}$ See: https://vk.com/edina_ukr.
} 
Shevchuk \& Oliynyk, 2015). Such attacks have a long tradition in Ukraine. Many politicians and intellectuals of national leanings talking about two Ukraines, regarding half of the country to be Ukrainian in its language and ways, and the other half to be "creole" (Riabchouk, 2003). People in the latter were perceived as Russified Ukrainians who "had to be reconverted" to the Ukrainian language and nation. According to Bilaniuk (2010, pp. 116-117), it is as if many people in Ukraine would see a necessary connection between the ethnic and linguistic identity: ethnic Ukrainians must speak Ukrainian, Russians must speak Russian. According to this logic, the Russian-speaking Ukrainians are the proof of the existence of Russian imperialism, and steps should be taken in order to prevent the fall of the Ukrainian state and language (Bilaniuk, 2010, p. 117; Pavlenko, 2011, pp. 48-49).

Those who thought along these lines often categorized the population of the country into moral groups on an ethno-linguistic basis (Masenko, 2007, p. 57). Many considered people of Ukrainian ethnicity but of Russian mother tongue to be traitors or "janissary" (Kulyk, 2001, p. 211; Pavlenko, 2011, pp. 4849). The language exchange of the Russian-speaking Ukrainians is considered a moral offense (Shumlianskyi, 2010, p. 142). Hnatkevych (1999, p. 11) accuses those who speak to their children in Russian at home of the "degeneration of the Ukrainian nation", who are "infected" by the Russification as a "disease" and are not looking for a "cure". Due to the "deformed" language situation (Masenko, 2007, p. 7), a part of the political and social elite regarded as the primary language policy task of the state the strongest and widest propagation of the Ukrainian language (Matsyuk, 2009, p. 178).

The central idea of this attitude was that the shared Ukrainian language was a special symbol of the newly formed and unified political nation and "a means of strengthening the state's unity" (Concept, 2010). Thus, according to nationally inclined politicians, all those arguing for two state languages or believing that minority languages would be given official status are acting against the idea of a new Ukrainian state and a unified Ukrainian nation and state (Mayboroda \& Panchuk, 2008, pp. 207-209). They considered it all too natural that the Ukrainian people who gained state independence wanted to have Ukrainian monolingualism after a historically long period of forced and asymmetrical bilingualism (Shemshuchenko \& Horbatenko, 2008, p. 168). Those 
who regarded the linguistic state of the country as postcolonial (Masenko, 2004) were of the opinion that the struggle against the Russian language, forced on Soviet Ukraine as a language of "communication between nations", was a necessary part of the independence of the nation and the language as well as of Ukrainian self-consciousness. Yushchenko (2010) proclaimed that "the nation gains immunity against adversary influences from the outside only through forming a unified linguistic and cultural space".

Not surprisingly, the conciliatory language policy has been the subject of criticism after the new revolution. One of the best known Kyiv based linguistis, Larysa Masenko stated the following in an internet portal where language related issues are discussed regularly:

\begin{abstract}
"The currently popular slogan »Єдина країна - Единая страна« is faulty: it solidifies bilingualism on a country level, that is, it strengthens Russian as a second state language. In other words, it does not unify the country but divides it. By saying Единая страна in Russian we turn to those living in the east and assert that Ukrainian, which is a special symbol of the unification of the nation, is not obligatory, even for the president, and with this we betray Ukrainians, primarily those living in the east, who are loyal to their language despite the constant pressure from the Russian speaking environment" (Masenko \& Orel, 2014).
\end{abstract}

Yuri Shevchuk, a linguist teaching Ukrainian in the United States agrees: "The Ukrainian society has not only become a hostage to the 'united and indivisible' Russia's imperial formula 'Єдина країна, Единая страна' which confirms the Russification. With its resignation and conformism they take part in destroying their own language and culture" (Shevchuk, 2015).

Shevchuk also questions whether Russian speakers could be good patriots, "The hybrid war in the east broke out in the battleground of the culture and civilization as well. Previously, it was quite obvious who is a supporter of Ukrainians and who is an enemy in terms of language and culture. Now, however, the 'new' patriots' surprising idea appeared who love Ukraine, but do not love the Ukrainian language. This concept is doubtful to me" (Shevchuk \& Vlasiuk, 2015).

Citing a metaphorical parallel between the inhabitants of Gilead and Ephraim of the biblical Book of Judges (112, p. 56), known for bloody conflicts (see now Shibboleth/Sibboleth) and between the Ukrainian war, Shevchuk 
opposed the Ukrainian-Russian bilingualism for all kinds of manifestations: "The linguistic schizophrenia deprives the protective role from the Ukrainian language in the existential situations when your life is in danger, and based on your language you can distinguish ours from the enemy" (Shevchuk \& Palazhyi, 2015).

He believes that those who propagandize bilingualism use Ukrainian as a decorative mask in linguistically schizophrenic situations, and in fact seek a Russian-speaking monolingualism:

"The Ukrainian language is necessary for the russification programs only because they can hide behind it. If they withdrew Ukrainian and kept only Russian, then everyone would understand that we are exposed to russification, and if we have some Ukrainian sprinkled on top, we get a situation in which is needed in the field of cultural hybrid war: one cannot know who is the enemy and who is a friend, who undermines the Ukrainian identity, and who is supporting" (Shevchuk \& Palazhyi, 2015).

So there are opinions according to which the new political elite continues the policy of russification of the earlier eras, but now under a patriotic camouflage. The Chairman of the national coordination council in defence of the Ukrainian languages saw this situation like this in the summer of 2015:

\begin{abstract}
"Changing the russification of 'doves' and 'hawks' of the Russian Empire and the Soviet Union a post-revolutionary period occurs, the 'patriotic russification'. Now under the noble slogan 'single country' the 'standardization' of the linguistic space continues in such a way that the Ukrainian language is not to 'chase rights' of the Russian-speaking patriots" (Marusyk, 2015).
\end{abstract}

Masenko (2015) is suspiciously eyeing the Russian-speaking part of the Ukrainian society: "The victory in the linguistic and cultural war with Ukraine was a prerequisite for Russia in the current military intervention, and the occupation of Donbass and the Crimea. And planning the revitalization of the Soviet empire, the Kremlin is counting on those parts of the Ukrainian population which could be 'crystallized' by the control of the mass media."

According Marusyk (2016a), "The process of decommunization which is still ongoing, cannot be completely successful without starting the process of decolonization and derussification". 
Many consider that the sacrifice made by Russian native speakers on the front line for Ukraine is not enough. A Ukrainian writer explains in one of the entries in a language policy portal on Russian-speaking people fighting against separatists: "Somehow we should make them believe, that their Moscow language is their personal sin against Ukraine [...]; against the Ukraine, for which, literally, they shed their blood" (Matsyuk, 2015). According to him, the Russian-speaking Ukrainians also have to be convinced that the Russian language in Ukraine is not worth the blood sacrifice. And then he asks the question: "When will they [the Russian-speaking Ukrainians] leave the Russian speech which has only been their mother tongue since the second generation? This will be the redemption of their original sin, which is more expensive for Ukraine than their blood" (Matsyuk, 2015).

In the next article the same writer states that the Russian-speaking Ukrainian citizens want to continue their privilege inherited from the Soviet era and not taking up arms for the country, "they fight for the liberal Ukraine for their own children, who will reign in the Ukrainian-speaking plebs. [...] The Russianspeaking volunteers should finally realize their sins of their Russian speech" (Matsyuk, 2016).

The battlefield sacrifice of the Russian-speaking is being reduced by sociological research. For example, a survey published 6 June 2016, points out that among the participants of the ATO $73 \%$ are of Ukrainian mother tongue, $6 \%$ of Russian and $19 \%$ of the Ukrainian-Russian-speaking rate; however, among those informants who are not involved in the ATO, the proportion of native speakers of Ukrainian is only 55\%; however, $19 \%$ are Russian-speaking and $23 \%$ are bilingual. So there is a bigger proportion of the Ukrainian-speakers in the ATO than amongst those who are not involved in the fights.

Civil movements are protesting against the missing Ukrainian nationalization. On the 9 November 2015 (the Ukrainian language and literacy day) a movement in front of the presidential office announced claims to provide 
special status of the Ukrainian language, the motto was "Ukrainization resistance against the occupation." ${ }^{14}$

"The [...] language law was written on Putin's knee, and had a different purpose. The president keeps talking about the protection of the Ukrainian language, but nothing happens. We are tired of demagoguery. A war is going on here, the Russian propaganda pours from the screen, and no one does anything about it" - said one of the protesters. ${ }^{15}$

Every year on 9 November the Ukrainian Literacy Day is celebrated. On this occasion a one and a half minute video was made where volunteers in eastern Ukraine who took part in battles, tell their ideas on Ukrainian politics. ${ }^{16}$ The words of the volunteers indicate, how the Ukrainian national side sees the role of the Ukrainian and Russian languages, objectives and tasks of the wartime language policy. The first interviewee, said: "I grew up in a Russian-speaking family. After the Maidan I switched to the use of the Ukrainian language, because I realized that the best resistance against the Russian aggression is if we speak Ukrainian".

The next interviewee, in the uniform of the National Guard, considered that as long as we speak the same language with the enemy, they "think we are all the same and bring troops again and again to 'liberate' us and annex us to themselves". Another volunteer, wearing a uniform stated: "enemies (...) openly claim that where the Russian language is, there is the Russian interest". People appearing on the video claim that "we did our best on the front line, but we may lose another war: the fight for our language and nationality".

Finally they summarized the essence of the message: "If you do not want the Russian soldiers to come and 'liberate' you and your loved ones use the most powerful weapon against them: speak Ukrainian! Switch to Ukrainian! Demand a strong support from the government of the Ukrainian language! Remember: the key to peace in the Ukrainian language, Ukrainian language is our safety."

The public radio and television council published a press release on 18 November 2015 where they express a concern that the proportion of the

\footnotetext{
14 See: http://language-policy.info/2015/11/scho-mozhna-zrobyty-u-den-ukrajinskojipysemnosti-ta-movy/.

${ }^{15}$ See: http://language-policy.info/2015/11/na-bankovij-protestuvaly-proty-rusyfikatsiji/.

${ }^{16}$ See: http://language-policy.info/2015/11/vijskovi-ta-volontery-zaklykayut-spilkuvatysyaukrajinskoyu-video/.
} 
Ukrainian language programs is declining in the electronic media; then they draw a parallel between the expansion of the Russian language and the war: "The modern history of Ukraine, unfortunately, is an example that after a language invasion a military invasion occurs."

According to Masenko (2016a), "the Russian language is the chain that bounds Ukraine to the Communist past". Masenko (2016b) stated that "an individual can be bilingual, but a bilingual nation did not exist. The peoples, in modern terminology, are united by the nation's own national language and distinguishes it from others." Then he closes the paper: "The Russian-speaking patriot who does not want to speak Ukrainian, protects the individual rights to use the language, which is the most comfortable to use; although, the Ukrainianspeaking patriots do not only protect the rights of the individual's own choice of language, but also the rights of the entire Ukrainian community for a dignified existence as a free nation."

Extension of the scope of use of the Ukrainian language, the obstruction of the Russian language is considered by many as a split from the colonial past Soviet era and means freedom and independence. At the 25th anniversary of the Ukrainian independence, scheduled for 24 August, a nationwide campaign of young people was announced, the slogan was: "Be truly independent: speak Ukrainian!"17

\section{The New Drafts of Language Law}

Based on the foregoing, the crisis in Ukraine and the language problems are connected by multiple threads. In its brief 25 -year history, the country has faced various crises. In the domestic political crises, the language issue has been constantly present: the political elite used the language issue as a mobilizing force for the election mood-enhancing factor to their own use. The language issue could become a division factor instead of a cohesion factor for a nation that is seeking identity after the collapse of the Soviet system. In the tense political situation, the language issue has become a pretext for military intervention; it

\footnotetext{
17 Available online: http://language-policy.info/2016/08/movomarafon-25-do-richnytsinezalezhnosti-ukrajintsi-perehodytymut-na-ukrajinsku-movu/.
} 
has become a casus belli. In the conflict of the increased Russian nationalism and the growing Ukrainian nationalism language plays the central role.

The Ukrainian nationalism sees the Russian language as the aggressor, as the enemy's language and the spread of the Ukrainian language is connected to the country's independence, winning the war in the east and the independence. Simultaneously, however, the imperial nationalism in Russia, apparently for statesupported shows on the Ukrainian nationalism as a response to the annexation of the Crimea and the Ukrainian military intervention. This further strengthens the concerns about Ukraine and the Ukrainian language. Therefore, more and more strongly demand the ukrainization from the government. As a result, several new draft laws were made.

The draft of the new Education Law ${ }^{18}$, which was brought in front of the Parliament on 19 October 2016, greatly reduces the language of the minorities in education, virtually eliminates the non-Ukrainian-language in higher education in the country. However, this step shall also cause conflicts. This indicates that the 15 leaders (Russian, Hungarian, Bulgarian, Jewish, Greek, Moldovan, Romanian, Gagauz and Roma) of ethnic minority organizations wrote an open letter to President Poroshenko to protest against the bill.

Four and a half years after the law was accepted - on 17 November 2016, based on the petition of 57 parliament representatives, submitted back on 7 July 2014, the constitutionality of the language law was examined. ${ }^{19}$

The concern about the language situation is reflected in the three language law drafts, which were submitted in December 2016 and January 2017 by the representatives of the Ukrainian parliament. The drafts registered as No. $5556^{20}, 5669^{21}$ and $5670^{22}$ grant far less right to use minority languages compared to the language law, adopted in 2012 (Tóth \& Csernicskó, 2017).

\footnotetext{
18 Проект Закону України «Про освіту». Retrieved from: http://w1.c1.rada.gov.ua/pls/zweb2/webproc4_1?pf3511=58639.

19 See: http://www.ccu.gov.ua/novyna/17-lystopada-konstytuciynyy-sud-ukrayiny-u-formiusnogo-sluhannya-rozpochav-rozglyad-spravy.

20 Проект Закону України «Про мови в Україні» Retrieved from: http://w1.c1.rada.gov.ua/pls/zweb2/webproc4_1?pf3511=60750.

21 Проект Закону України «Про функціонування української мови як державної та порядок застосування інших мов в Україні». Retrieved from: http://w1.c1.rada.gov.ua/pls/zweb2/webproc4_1?pf3511=60952.

22 Проект Закону України «Про державну мову». Retrieved from: http://w1.c1.rada.gov.ua/pls/zweb2/webproc4_1?pf3511=60953.
} 
According to Article 1 of the $5669^{\text {th }}$ draft law, political discourse initiated about bilingualism is against the law:

\begin{abstract}
"Attempts to introduce official multilingualism at national level against the Constitution of Ukraine and the established constitutional procedures are actions aimed at inciting ethnic hatred, linguistic division of the country, a violation of the constitutional order and territorial integrity of Ukraine."
\end{abstract}

\title{
Conclusions
}

Language policy issues usually become visible when (nation) states are searching for their identity and justification for their existence in political, economic or cultural transition periods. In general, these situations may involve varying levels of national or international periods of turmoil (war, armed or ideological conflict, economic recession, etc.). In Ukraine, the language policy is a form of response to political, economic and social crises.

Ukraine today is a state that has been in a transitional period since the proclamation of its independence 25 years ago: it seeks the leaven, which can be the basis for a new national identity. Unfortunately, the Ukrainian language policy did not contribute to this search and could not come up with valid solutions for the crisis. Many people hope to end the current crisis with the victory of romantic nationalist tendencies in Ukraine, and above the speakers of the one and only language, a single homogeneous nation-state extends its protective wings. There is a chance for this to happen.

In Ukraine, 25 years after the declaration of independence, in the majority of public language domains, it is still Russian that prevails, especially in the media and the economy, but the use of Ukrainian is not exclusive even in public administration. In November 2016, the state of war enhanced national cohesion and the loyalty to Ukraine. Just like in the euphoria following the Orange Revolution, there is again a chance for a new Ukrainian political state to be born. Besides the 25-year independence of the Ukrainian state and the Orange Revolution in 2004 - which set patriotic feelings on fire -, also the Revolution of Dignity ending in the forced retreat of Yanukovych's regime as well as the war going on since the spring of 2014 in some parts of the country the position of the Ukrainian language has been strengthening. Higher proportions of Ukrainian 
native speakers and thus the expansion of the Ukrainian language use are enhanced by the annexation of the mainly Russian-speaking Crimea and the fact that Kyiv has lost control over the also primarily Russian-speaking counties of Donetsk and Luhansk. Tens of thousands of refugees have left the Crimea and the eastern regions of Ukraine inflicted by fights, several of whom have gone abroad. With consideration to the war, Poland, the Czech Republic, Greece and Hungary have been assisting their linguistic minorities in relocating. Ukraine is therefore becoming increasingly more homogeneous from the ethnic and linguistic point-ofview. The currently bilingual country can become monolingual gradually.

But if this is associated with the ethnic and linguistic homogeneity, the strengthening of the romantic nationalist ideology and placing the nation-state unity above all, this new position will cause new conflicts in the globalized $21^{\text {st }}$ century which is based on cooperation and transfer of knowledge.

Recent events suggest that the national romanticism and nationalism will prevail and that the new Ukrainian political power will use the current crisis to strengthen the Ukrainian dominance. The new intention towards the abolition of the Language Act of 2012, as well as the new language law drafts consider a model of a monolingual nation-state as its objective.

It seems that the Ukrainian state leaders do not see the value and exploitable resources in the widespread Ukrainian-Russian bilingualism of the country. They drew the conclusion from the events of the recent past that minority languages threaten the country's security. However, in the circumstances of the current serious crisis this policy does not contribute to social consolidation, nor reconciliation and does not solve the crisis.

Susan Gal wrote in her now classic book that for a long time researchers believed that the language of people can be identified by their culture and nationality. On this basis, it was concluded that the widespread bilingualism is "an anomaly and therefore paid attention to it as a problem in its own right. (...) Therefore, depending on the ideological commitment nationality of the scholar and the political climate of the time, bilingualism in a community could be taken as indication of a variety of socio-political problems. It could provide evidence of the community's mixed ethnic loyalties and thus of a threat to the ideal of an ethnically homogenous nation state" (Gal, 1979, p. 2). This primordial, national 
romantic view that makes the Ukrainian language and the (free and independent) Ukrainian nation the same nowadays strongly dominates in Ukraine.

\section{References}

Besters-Dilger, J. (Ed.) (2009). Language policy and language situation in Ukraine: Analysis and recommendations. Frakfurt am Main: Peter Lang.

Bilaniuk, L. (2010). Language in the balance: The politics of non-accommodation on bilingual Ukrainian-Russian television shows. International Journal of the Sociology of Language, 210, 105-133.

Bowring, B. (2014). The Russian language in Ukraine: Complicit in genocide, or victim of state-building? In L. Ryazanova-Clarce (Ed.), The Russian Language Outside the Nation (pp. 56-78). Edinburgh: Edinburgh University Press.

Brubaker, R. (1996). Nationalism reframed: nationhood and the national question in the new Europe. Cambridge: Cambridge University Press.

Csernicskó, I. (2017). Language policy in Ukraine: The burdens of the past and the possibilities of the future. In S. E. Pfenninger \& J. Navracsics (Eds.), Future Research Directions for Applied Linguistics (pp.120-148). Bristol: Multilingual Matters.

Csernicskó, I. \& Ferenc, V. (2016). Transitions in the language policy of Ukraine (1989-2014). In M. Sloboda, P. Laihonen \& A. Zabrodskaja (Eds.), Sociolinguistic Transition in Former Eastern Bloc Countries: Two Decades after the Regime Change (pp. 349-377). Frankfurt am Main: Peter Lang.

Gal, S. (1979). Language shift: Social determinants of linguistic change in bilingual Austria. Academic Press.

Galeotti, M. (2015). "Hybrid war" and "Littler green man”: How it works, and how it doesn't. In A. Pikulicka-Wilcewska \& R. Sakwa (Eds.), Ukraine and Russia: People, Politics, Propaganda and Perspectives (pp. 156-164). Bristol: E-International Relations Publishing.

Concept (2010). Концепція державної мовної політики [The Concept of State Language Policy]. Retrieved from http://zakon4.rada.gov.ua/ laws/show/161/2010. 
Hnatkevych, Y. (1999). Чи злетить птах у синє небо? Нариси про русифікованих $і$ русифікаторів та гірку долю української мови в незалежній Україні [Can A Bird Take off in the Blue Sky? Essays on Russified and Russifiers and Bitter Fate of the Ukrainian Language in Independent Ukraine]. Київ: Просвіта.

Korostelina, K. V. (2013). Mapping national identity narratives in Ukraine. Nationalities Papers, 41(2), 293-315.

Kulyk, V. (2001). The politics of ethnicity on post-soviet Ukraine: Beyond brubaker. Journal of Ukrainian Studies, 26(1-2), 197-221.

Kulyk, V. (2014). What is Russian in Ukraine? Pupular beliefs regarding the social roles of the language. In L. Ryazanova-Clarce (Ed.), The Russian Language Outside the Nation (pp. 117-140). Edinburgh: Edinburgh University Press.

Lozyns'kyi, R. (2008). Мовна ситуація в Україні (суспільно-географічний погляд) [Language Situation in Ukraine (Human-Geographical View]. Львів: Видавничий центр ЛнУ імені Івана Франка.

Matsyuk, H. (2009). Прикладна соціолінгвістика. Питання мовної політики [Applied Sociolinguistics. The Question of Language Policy]. Львів: Видавничий центр ЛнУ імені Івана Франка.

Matsyuk, R. (2015). Гріх [Sin]. Портал мовної політики November 12, 2015. Retrieved from http://language-policy.info/2015/11/roman-matsyukhrih/.

Matsyuk, R. (2016). За що гинуть російськомовні? [Why Die Russian Speakers?] Портал мовної політики 1 January 2016. Retrieved from http://languagepolicy.info/2016/01/za-scho-hynut-rosijskomovni/.

Mayboroda, O. \& Panchuk, M. (2008). Мовне та політико-ідеологічне протистояння в Україні: причини, чинники, прояви [Linguistic and Political-Ideological Opposition in Ukraine: Reasons, Factors and Manifestation]. In Mayboroda, O. et al. (Eds.), Мовна ситуація в Україні: між конфліктом і косенсусом [Language Situation in Ukraine: Between Conflict and Consensus] (рр. 205-234). Київ: ІПіЕНД ім. І. Ф. Кураса НАН України.

Marusyk, Т. (2015). Чиїми «молитвами» закон Колесніченка-Ківалова живе й перемагає [Whose "Prayers" Law Kolesnichenko-Kivalov Lives and Wins]. Портал мовної політики 2015.6.16. Retrieved from http://language- 
policy.info/2015/06/taras-marusyk-chyjimy-molytvamy-zakonkolesnichenka-kivalova-zhyve-j-peremahaje/.

Marusyk, Т. (2016а). День слов'янської писемності і культури: декомунізація буде неповна без дерусифікації [Day of Slavic Literature and Culture: Decommunization will be Incomplete without De-Russification]. Портал мовної політики 12 June 2016. Retrieved from http://languagepolicy.info/2016/06/den-slov-yanskoji-pysemnosti-i-kulturydekomunizatsiya-bude-nepovna-bez-derusyfikatsiji/.

Marusyk, Т. (2016b). «Мовний закон» Ківалова-Колесніченка: Троянські коні Кремля [The Kivalov-Kolesnychenko's "Language Law": The Trojan Horses of Kremlin]. Портал мовної політики November 8, 2016. Retrieved from http://language-policy.info/2016/11/movnyj-zakonkivalova-kolesnichenka-troyanski-koni-kremlya/.

Masenko, L. (2004). Мова і суспільство: постколоніальний вимір [Language and Society: Post-Colonial Dimension]. Київ: Видавничий дім „КиєвоМогилянська академія".

Masenko, L. (2007). (У)мовна (У)країна. [Conditional Ukraine/Linguistic Country] Київ: Темпора.

Masenko, L. (2015). Мовознавча солідарність по-українськи [Linguistic Solidarity in Ukrainian]. Портал мовної політики 24 September 2015. Retrieved from: http://language-policy.info/2015/09/larysa-masenkomovoznavcha-solidarnist-po-ukrajinsky/.

Masenko, L. (2016a). Скандал в Охматдиті як дзеркало пострадянської мовної політики [Scandal in Ohmatdyt as a Mirror of the Post-Soviet Language Policy]. Портал мовної політики August 29, 2016. Retrieved from http://language-policy.info/2016/08/skandal-v-ohmatdyti-yak-dzerkalopostradyanskoji-movnoji-polityky/.

Masenko, L. (2016b). Якою мовою говорить патріотизм? [What Language Does the Patriotism Speak?] Портал мовної політики. Retrieved from http://language-policy.info/2016/11/yakoyu-movoyu-hovorytpatriotyzm/.

Masenko, L. \& Orel, M. (2014). Нам потрібен мовний кордон із Росією. Сучасна мовна політика в Україні очима соціолінгвіста [We Need a Language Border with Russia. The Current Language Policy in Ukraine through the 
Eyes of Sociolinguists]. Портал мовної політики 26 December 2014. Retrieved from http://language-policy.info/2014/12/nam-potribenmovnyj-kordon-iz-rosijeyu-suchasna-movna-polityka-ukrajini-ochymasotsiolinhvista/.

Opinion (2011). Opinion on the draft law on languages in Ukraine. Adopted by the Venice Commission at its 86th Plenary Session (Venice, 25-26 March 2011). Retrieved from: http://www.venice.coe.int/webforms/documents/ ?pdf=CDL-AD(2011)008-e.

Osnach, S. (2015). Мовна складова гібридної війни [The Linguistic Components of the Hybrid War] Портал мовної політики 13 June 2015. Retrieved from http://language-policy.info/2015/06/serhij-osnach-movna-skladovahibrydnoji-vijny/.

Pavlenko, A. (2008). Multilingualism in post-soviet countries: Language revival, language removal, and sociolinguistic theory. The International Journal of Bilingual Education and Bilingualism, 11(3-4), 275-314.

Pavlenko, A. (2011). Language rights versus speakers' rights: On the applicability of western language rights approaches in Eastern European contexts. Language Policy, 10, 37-58.

Polese, A. (2011). Language and identity in Ukraine: Was it really nationbuilding? Studies of Transition States and Societies, 3(3), 36-50.

Riabchouk, M. (2003). Дві України: Реальні межі, віртуальні війни [Two Ukraines: Real Boundaries and Virtual Wars]. Київ: Критика.

Shemshuchenko, Y. \& Horbatenko, V. (2008). Законодавство про мови в Україні: хронологічний моніторинг, класифікація, понятійна основа [Legislation on Languages in Ukraine: Chronological Monitoring, Classification, Concepts]. In O. Mayboroda et al. (Eds.) Мовна ситуація в Україні: між конфліктом і консенсусом [The Language Situation in Ukraine: Between Conflict and Consensus] (рр. 157-173). Київ: Інститут політичних і етнонаціональних досліджень імені І. Ф. Кураса НАН України.

Shevchuk, Y. (2015). Мовна шизофренія. Quo vadis, Україно? [Linguistic schizophrenia: Quo vadis, Ukraine?]. Івано-Франківськ: Discursus.

Shevchuk, Y. \& Oliynyk, Y. (2015). Російськомовними патріотами маніпулюють [Russian-speaking Patriots Manipulated]. Портал мовної політики 
20 June 2015. Retrieved from http://languagepolicy.info/2015/06/rosijskomovnymy-patriotamy-manipulyuyutvykladach-kolumbijskoho-universytetu/.

Shevchuk, Y. \& Palazhyi, H. (2015). Мовна шизофренія - нова, потужна форма русифікації [Linguistic Schizophrenia - a New, Powerful Form of Russification]. Портал мовної політики September 19, 2015 Retrieved from http://language-policy.info/2015/09/yurij-shevchuk-movnashyzofreniya-nova-potuzhna-forma-rusyfikatsiji/\#more-1780.

Shevchuk, Y. \& Vlasiuk, H. (2015). Двомовність як хвороба. Професор Колумбійського університету називає українську мовну ситуацію «мовною шизофренією» [Bilingualism as a Disease: Columbia University Professor Evaluate's Ukraine's Language Situation as "Linguistic Schizophrenia"]. Портал мовної політики July 5, 2015. Retrieved from http://language-policy.info/2015/07/dvomovnist-yak-hvoroba-profesorkolumbijskoho-universytetu-nazyvaje-ukrajinsku-movnu-sytuatsiyumovnoyu-shyzofrenijeyu/.

Shumlianskyi, S. (2010). Conflicting abstractions: Language groups in language politics in Ukraine. International Journal of the Sociology of Language, 201, 135-161.

Taranenko, O. (2007). Ukrainian and Russian in contact: Attraction and estrangement. International Journal of the Sociology of Language, 183, 119-140.

Tóth, M. \& Csernicskó, I. (2017). Нові засади мовного регулювання в Україні у дзеркалі конституційно-правового аналізу національного законодавства та міжнародних зобов'язань України [The New Principles of Language Regulation in Ukraine in the Mirror of the Constitutional and Legal Analysis of National Legislation and International Obligations of Ukraine]. In A. Márku \& E. Tóth (Eds.), Többnyelvüség, regionalitás, nyelvoktatás [Multilingualism, Regionality, Language Teaching] (pp. 8499). Ungvár: RIK-U.

Ulasiuk, I. (2012). The Ukrainian language: What does the future hold? (A legal perspective). In A. Milian-Massana (Ed.), Language Law and Legal Challenges in Medium-Sized Language Communities. A Comparative Perspective (pp. 25-51). Barcelona: Institut d'Estudis Autonòmics. 
UN (2014). Ukraine: UN Special Rapporteur urges stronger minority rights guarantees to defuse tensions. United Nations Human Rights Office of the High Commissioner. Retrieved from http://www.ohchr.org/EN/NewsEvents/Pages/DisplayNews.aspx?NewsID= 14520.

Vynnychuk, Y. (2016). На мовному фронті без змін! [On the Linguistic Front No Change!]. Портал мовної політики May 5, 2016. Retrieved from http://language-policy.info/2016/05/na-movnomu-fronti-bezzmin/\#more-3020.

Yushchenko, V. (2010). Чия мова - того й влада [Whoever Rules the Language Has the Power]. День No. 180, 6 жовтня 2010.

\section{István Csernicskó}

Ferenc Rákóczi II. Vengru Trans-Karpatu institutas, Ukraina; Panonijos universitetas, Vengrija csernicsko.istvan@gmail.com

\section{Réka Máté}

Panonijos universitetas, Vengrija; Ferenc Rákóczi II. Vengru TransKarpatu institutas, Ukraina

suto.reka93@gmail.com

\section{DVIKALBYSTĖ UKRAINOJE: VERTYBĖ AR IŠŠŪKIS?}

Santrauka. Lingvistinè Ukrainos situacija aptarta daugelyje tyrimu, kuriuose nagrinèjamos ivairios ukrainiečiu kalbos politikos problemos. Pagrindinès lingvistinès situacijos Ukrainoje problemos yra sutarimo trūkumas dèl to, koki vaidmeni ukrainiečiu kalba atlieka kuriant nauja posovietinę tapatybę ir tauta, bei koki statusą reikètu suteikti rusu kalbai. 2001-uju surašymo duomenimis, 80 \% suaugusiuju Ukrainoje laisvai kalba (bent) dar viena kalba, neskaitant gimtosios. Pastebima, kad šalies realybje vyrauja dvikalbystè. Beveik kiekvienas Ukrainos gyventojas yra dvikalbis; ivairiu mastu pagrindinis Ukrainos visuomenès bruožas yra dvikalbystè. Nepaisant to, dèl neigiamos istorinès patirties, dvikalbystè Ukrainoje stigmatizuojama, todèl jos kodifikacija valstybiniu mastu yra neimanoma. Šiame straipsnyje atskleidžiamas Ukrainos politiku, atėjusiu i valdžia po prezidento Viktoro Janukovyčiaus nuvertimo, požiūris i dvikalbystès problemą. Pristatome kalbininku ir intelektualu komentarus apie dvikalbystę Ukrainoje. Dabar vyrauja pirmapradis, nacionalistinis romantinis požiūris, kuris sutapatina ukrainiečiu kalbą ir (laisvą ir nepriklausoma) Ukrainos tauta.

Pagrindinès sąvokos: Ukraina, ukrainiečiu kalba, rusu kalba, kalbos politika, kalbos teisès. 